\title{
SEJARAH MELAYU JAMBI DARI ABAD 7 SAMPAI ABAD 20
}

\author{
Benny Agusti Putra \\ Fakultas Ilmu Budaya Universitas Jambi \\ Jl. Lintas Jambi - Muara Bulian Km. 15, Kota Jambi \\ bennyagustiputra@gmail.com
}

\begin{abstract}
Abstract: History of Malay Jambi From 7th Century to 20th Century. Some historians said that Malay was the first kingdom to control Jambi. The center of its kingdom in Jambi city is now also a legacy of the Malay Kingdom. Another thing about the existence of Malays in Jambi is that there are several records from China during the T'ang Dynasty that mentioned Mo-lo-yu. The author attempts to position the history of Jambi Malay in hopes of providing a formula amid increasingly complex life. Malay as the identity of Jambi society is very important in the Historiography "historical writing" in the archipelago of malay. This study will discuss three main topics, classical I and II Malay (Hindu Buddhism), Malay Malay II (Colonial Islam), Jambi Malay post-independence and the establishment of Jambi province. This research is a conceptual research, in which this research is a historiography "historical writing" of Malay writings. The sources of writing in this article come from previous studies.
\end{abstract}

Keywords: History, Melayu, Jambi.

Abstrak: Sejarah Melayu Jambi dari Abad 7 Sampai Abad 20. Sebagian sejarawan mengatakan bahwa Melayu merupakan kerajaan pertama yang menguasai Jambi. Pusat kerajaannya berada di kota Jambi sekarang juga merupakan peninggalan Kerajaan Melayu. Hal lainnya mengenai keberadaan Melayu di Jambi adalah adanya beberapa catatan dari Tiongkok pada zaman Dinasti T'ang menyebut Mo-lo-yu.Penulis berupaya memposisikan sejarah melayu Jambi dengan harapan memberikan sebuah formula ditengah kehidupan yang semakin komplek. Melayu sebagai identitas masnyarakat Jambi menjadi sangat penting didalam Historiografi "penulisan sejarah" Melayu di Nusantara. Penelitian ini akan membahas tiga topik utama, melayu klasik I dan II (Hindu Budha), melayu II (Islam Kolonial), Melayu Jambi pasca kemerdekaan dan pembentukan provinsi Jambi. Penelitian ini merupakan penelitian konseptual, yang mana penelitian ini adalah Historiografi "penulisan sejarah" Melayu terhadap tulisan-tulisan Melayu. Sumber-sumber penulisan artikel ini berasal dari penelitian-penelitian yang telah dilakukan sebelumnya.

Kata Kunci: Sejarah, Melayu, Jambi.

\section{Pendahuluan}

Jambi, secara geografis, terletak di bagian timur pulau Sumatera. Bagian paling timur Jambi adalah Tanjung Jabung Timur. Jambi merupakan wilayah yang strategis karena memiliki sungai yang panjangnya dari hulu (Sijunjung) langsung bermuara ke laut timur Sumatera (Tanjung Jabung) dan langsung bertemu dengan selat-selat penting di pantai timur Sumatera. ${ }^{1}$ Lingkungan alam Jambi terbagi atas lingkungan daratan dan perairan. Daratan Jambi secara umum didominasi dataran rendah. Kenampakan alam daratan selanjutnya berupa perbukitan, dataran tinggi, pegunungan, gunung, teluk dan tanjung. Kenampakan alam daratan ini berbaur dengan kenampakan alam perairan Jambi yang berupa sungai, danau, rawa, selat dan 
laut. Setiap bentuk kenampakkan alam ini mempunyai potensi dan manfaat yang berbeda bagi masyarakat Jambi. ${ }^{2}$

Dalam kronologi historis dari melayu I dan II (Hindu dan Bhuda), melayu III (Islam Kolonial), dan melayu Jambi kemerdekaan. Masih belum tuntas pembahasan beberapa kerajaan tua pada abad-abad sebelumnya, misalnya Kandali, Tufo, dan Koying. Nama kandali telah dikenal oleh pemerintahan Kaisar Hsianwu (469-464). Menurut catatan, raja dari Kandali bernama Sa-pa-la-na-hu-da menyuruh utusannya bernama Tarada untuk pergi ke negeri Cina sebagai utusan dagang dan persahabatan. ${ }^{3}$ Menurut catatan yang dibuat dalam pemerintahan Kaisar Wudari dinasti Liang (502-549) kerjaan Kandali mengirim utusan ke Cina pada tahun 502, 519, dan 520. Diberitakan bahwa Kandali berada di laut selatan dan barang dagangan yang terkenal adalah pakaian berbunga, kapas, dan pinang. Catatan Cina tersebut mengatakan kerajaan San-fo-si berada dilaut selatan anatara Kamboja (Chen-la) dan Jawa (hepo). Diterangkan dengan jelas bahwa raja San-fo-tsi (Sriwijaya) bersemanyam di Chan-pei (Jambi). ${ }^{4}$

\section{A. Pembahasan}

\section{a. Klasik Malayu I dan II (Hindu Budha)}

Zaman Hindu Budha di Jambi yang cukup andil adalah Slamet Mulyana, ia menyatakan dalam bukunya Kuntala, Sriwijaya, dan Surarnabhumi yang didukung oleh para pakar diantaranya J. Tokakusu, H. Kern, W.D Groeneveldt, G. Ferrand, P. Peliot, J.L. Moens, Paul Wheatly, O.W. Wolters yang mengatakan bahwa Malayu itu di Jambi dan Sriwijaya di Palembang yang keduanya-keduanya merupakan negara maritim. ${ }^{5}$ Rekonstruksi histori Jambi inilah yang melahirkan konsep bahwa jalur Sungai Batanghari dari hilir ke hulu menjadi tempat pusatpusatpemerintahan Malayu dan ibukota Malayu yang berpindah-pindah.

Abad-7 sampai pertengahan abad 13 M. Jambi telah beberapa kali diduduki oleh penguasa lokal, seperti penguasa seperti Melayu, Sriwijaya, dan Suarnabhumi. ${ }^{6}$ Dengan adanya penguasa yang menduduki Jambi, maka Jambi menjadi suatu wilayah yang mendapat perhatian dari negeri luar, karena ini merupakan peluang kerja sama dalam bidang perdagaangan antra negara luar dengan Jambi. Halini dikatakan demikian dikarenakan hubungan Jambi dengan negara luar lebih dominan pada hubungan perdagangan kemudian diplomasi. Sementara, letak Jambi secara geografis menguntungkan karena banyaknya pedagang interasional yang melintasi pesisir timur Sumatera dan menggunakan jalur DAS Batanghari sebagai akses keluar masuknya para pedagang tersebut ke dalam Jambi, memberikan keuntungan tersendiri bagi Jambi dalam hal ekonomi. Kemudian juga bisa menjalin hubungan diplomasi dengan negara luar yang datang ke Jambi dengan misi berdagang.

Secara historis ada suatu fase didalam perkembngan melayu klasik. Menurut Djafar mengungkapkan bahwa antara kerajaan Melayu dan Kerajaan Sriwijaya sering membingungkan. Kerancuan-kerancuan ini terjadi dalam hal kronologi dan wilayah kerajaan. Seperti dimaklumi kerajaan Melayu dan kerajaan Sriwijaya memiliki masa perkembangan 
yang relatif sama waktunya, dan dan memiliki wilayah kerajaan yang hampir bersamaan secara geografis. Dari sumbersumber tertulis yang ada, terutama berita Cina, dapat diketahui suatu fase dalam sejarah kerajaan Melayu yang merupakan fase pendudukan oleh Sriwijaya. Fase pendudukan ini pada suatu ketika berkahir, dan kerajaan Melayu merdeka kembali. Dengan demikian dapat diketahui bahwa ada tiga fase delam sejarah perkembangan kerajaan Melayu, yaitu: fase I adalah fase awal, sekitar pertengahan abad ke-VII atau tahun 680 masehi. Fase ke II, masa pendudukan kerajaan Sriwijaya, kejadian ini sekitar tahun 680 sampai pertengahan abad ke-11. Fase ke III, adalah masa akhir kerajaan Melayu, sekitar pertengahan abad ke-11 sampai akir abad ke-14 dan awal abad 15.7

Jambi pernah dikuasai oleh Sriwijaya, dibuktikan dengan catatan ITsing saat dua kalinya ia singgah di Molo-yu. Sebelumnya telah dijelaskan bahwa kunjungannya yang kedua setelah pulang dari India Mo-lo-yo telah menjadi wilayah bawahan Sriwijaya. ${ }^{8}$ Kemudian masih ada lagi bukti mengenai Sriwijaya pernah menduduki Jambi, yakni ditemukannya Prasasti Karang Brahi, Yang ditemukan di hulu sungai Batanghari. ${ }^{9}$ Menjadi kedatuan yang besar, Sriwijaya menguasai perairan pulau Sumatera hingga selat Sunda. Lalu lintas perdagangan di perairan inidiataur dan diawali oleh Sriwijaya, Kemudian ia membangun pelabuhan di pedalaman Jambi, dengan demikian banyaknya pelayaran yang masuk ke Jambi melalui jalur sungai Batanghari, sehingga hubungannya dengan negara luar terjalin dengan baik di bidang ekonomi, salah satu negara yang menjalin hubungan baik dengan Jambi adalah Cina. ${ }^{10}$ Dengan bukti inilah permulaan bahwa Jambi telah banyak disinggahi oleh bangsa-bangsa dari negara luar. Orang-orang ini bukannya melakukan misi dagang, tetapi dengan misi dakwah. Dengan demikian, orangorang atau pedagang dari Cina pada saat itu juga menyebarkan ajaran Budha dan India menyebarkan agama Hindu. Sriwijaya hanya berkuasa di Jambi cuman dua abad. Dikarenakan Sriwijaya yang semakin merajalela mengusai Jambi dan perairan timur Sumatera sebgai lalu lintas penting dalam akses perdagangan dunia. Ia menaikan pajak para pelayaran dan memwajibkan sistim masuk terlabih dahulu ke Jambi sebelum melanjutkan perdagangan ke wilayah lain, dan banyaknya para peropak di perairan timur Sumatera yang perompak merupakan bawahan Sriwijaya.11 Dengan kondisi tersebut, memicu banyaknya yang tidak mematuhi peraturan yang dikeluarkan oleh Sriwijaya dan pedagang atau pelayaran yang melintasi pantai timur Sumatera mengambil jarak sehingga pelayarannya saat itu melintasi Selat Makala dan semenanjung Malaya tidak diketahui oleh penjara perairan tersebut. Dengan demikian pemasukan Sriwijaya mulai menipis dan kepercayaan perompak kepada Sriwijaya mulai berkurang sehingga adanya pertempuran antara hulubalang Sriwijaya dengan perompak yang dahulu menjadi bawahannya. ${ }^{12}$

Kondisi Sriwijaya semakin menurun tampuk kekuasaannya di Jambi. timbul penguasa baru di Jambi, penguasa yang melirik adalah Suarnabhumi. Suwarnabhumi mengambil alih kekuasaan di Jambi, dan mampu 
mengusir Sriwijaya dari tanah Jambi pada tahun 866 Masehi. Selanjutnya keingigan Suwarnabhumi menguasai Jambi adalah ingin perbaiki sistem pemerintahan dan memperbaiki hubungan antara Jambi dengan negara luar dan menjalalin hubungan negara-negara terkenal lainnya, seperti semenanjung Arab. Pada masa ini, mulai banyak pedagang yang berasal dari Arab masuk Jambi. namun tetap fokus kekeraban Jambi pada Tiongkok. Beberapa kali Suwarnabhumi mengirim utusan ke Cina pada abad ke 9 samapai 11.13

Setelah Sriwijaya mengalami masa kemundurannya pada sekitar abad ke 12, kerajaan Melayu mulai bangkit kembali. Pada tahun 1347 Adityawarman berada di Malayu, daerah asal ibundanya, menggantikan Raja Mauliwarmadewa dan dinobatkan menjadi Maharaja Diraja bukan saja untuk kerajaan Melayu Jambi juga untuk seluruh Sumatera. Kedudukannya saat itu dinamakan dengan raja Swarnabumi. ${ }^{14}$

Pada tahun 1341 M sekitar abad 1213 kerajaan melayu mengalami perkembngan pesat, menurut Bambang Budi Utomo didalam buku Batanghari Riwayatmu Dulu, puncak kejayaan pada masa pemerintahan Adityawarman dengan pusat kekuasaannya di daerah hulu Batanghari. Pada masa itu logam emas dimanfaatkan semaksimal mungkin, seperti dipakai sebagai bahan lempengan emas, benang emas, lembaran emas bertulis, kalung dan arca. Meskipun kerajaan berlokasi di daerah hulu Batanghari di wilayah Minangkabau, Adityawarman tidak pernah menyebut daerah kekuasaannya sebagai kerajaan Minangkabau, ia menamakan dirinya sebagai kanakamedinindra, yang berarti penguasa negeri emas. Dengan demikian ia menganggap dirinya sebagai penguasa daerah-daerah yang dulunya menjadi daerah kekuasan kerajaan Srwijay). ${ }^{15}$ Adityawarman adalah putra Majapahit keturunan Melayu, sebelum menjadi raja Melayu ia pernah menjabat kedudukan wrddha-mantri di Majapahit dengan gelar Aryadewata pu Aditya. Setelah ia berkuasa di Sumatera ia menyusun kembali kerajaan yang diwariskan oleh Mauliwarmadewa.

Pada tahun 1347 Adityawarman meluaskan daerah kekuasaannya sampai ke daerah Pagarruyung, ia mengangkat dirinya menjadi seoranng maharajadhiraja dengan gelar Udayadityawarman atau Adityawarmodaya pratapaparakramarajendra Maulimaliwarmadewa. Tetapi meskipun demikian Adtyawarman masih tetap menganggap dirinya sebagai sang mantri terkemuka dari Majapahhit. Dari prasastiprasastinya dapat diketahui bahwa Adityawarman adalah penganut agama Budha dan menganggap dirinya sebagai penjelmaan Lokeswara. Anggapan ini sesuai dengan sistem kalacakra seperti halnya raja-raja Majapahit. Adityawarman memerintah hingga sekitar tahun 1375, sebagai penggantinya adalah anaknya sendiri yang bernama Anangwarman, hanya tidak diketahui dengan jelas kapan ia menggantikan kedudukan ayahnya itu. ${ }^{16}$

Meskipun

Adityawarman memperluas wilayah kerajaannya ke Barat, namun ia tetap menyatakan dirinya sebagai kerajaan Malayu Werdhamantri di Keraton Majapahit. Adityawarman wafat pada tahun 1376 merupakan seorang figur yang tidak dilepaskan dari sejarah 
kerajaan Minangkabau. Setelah Adityawarman wafat, ia digantikan oleh putranya yang bernama Maharaja Mauli (Ananggawarman). Kerajaan Pagarruyung di bawah pimpinan Ananggawarman berusaha untuk melepaskan diri dari kekuasaan kerajaan Majapahit. Pertempuran yang maha dahsyat yang membawa banyak korban terjadi di Padang si Busuk pada tahun 1409 yang membawa akibat amat atal bagi kerajaan Pagarruyung. Nagari-nagari mulai memisahkan diri dan beronotomi penuh, Islam pun mulai menyebar di Minangkabau. Kemungkinan besar sekitar abad ke 15 inilah salah seorang keturunan Adityawarman bernama puteri Selaro Pinang Masak (Selaras Pinang Masak) yang berada di Pagarruyung kembali ke daerah asalnya yaitu kerajaan Melayu (Dharmasraya-Jambi). ${ }^{17}$ Kembalinya puteri Selaras Pinang Masak ${ }^{18}$ ini ke Melayu dengan menelusuri Sungai Batang Hari dan melepaskan Angsa Putih (kemudian lebih dikenal dengan sebutan Angso Duo). Tempat dimana puteri ini melepaskan sepasang angsa tersebut tidak terdapat keterangan secara pasti, diduga dilepaskan dari Siguntur, dengan pertimbangan bahwa disana adalah tepi huluan sungai Batang Hari berdiri sebuah istana, lagi pula Siguntur letaknya tidak jauh dari Sungai Langsat, daerah ditemukannya prasasti-prasasti dan patung-patung peninggalan Adityawarman.

\section{b. Melayu III (Islam Kolonial)}

Jatuhnya Malaka ke tangan Portugis pada tahun 1511 mengembuskan kehidupan ke pelabuhan Jambi, Palembang dan Banten, sehingga dalam bagian kedua abad XVI mengalami perkembangan pesat. Ekspansi Aceh dengan sistem monopolinya dan kemudian dengan kedatangan-pedagang Barat lain menjadi faktor pendorong kuat bagi pertumbuhan pelabuhan-pelabuhan tersebut.Jambi muncul sebagai pengekspor lain yang penting oleh karena daerah pedalamannya sampai Minangkabau adalah penghasil lada besar. Di sebelah utara, Jambi menghadapi bahaya ekspansi dari Kerajaan Aceh. Setelah Portugis menaklukkan Kedah, Perak, Pahang dan Johor, kemudian Tiku dan Pariaman di Pantai Barat Sumatera ditundukkan pula. Jadi ada dua ancaman langsung terhadap Jambi. Baik pihak Portugis maupun VOC sama sekali tidak menghendaki Jambi ke tangan Aceh. Pada satu pihak Jambi adalah pelabuhan ekspor lada dan pada pihak lain menjadi pengimpor beras dan garam, maka masih ada ketergantungan ekonomis kepada Jawa (Demak Mataram). Pengaruh Jawa masih kuat selama bagian pertama abad XVII. ${ }^{19}$

Pada umumnya kerajaan ini tidak mengadakan perlawanan dengan berperang, namun agitasi sering kali dilancarkan dan terutama pada abad XVII dengan diperkuat semangat keagamaan anti kafir. Mengenai hal ini intrik dan agitasi oleh pedagang-pengungsi Makassar di Banjarmasin, Johor, Jambi, Banten dan Madura sangat besar peranannya. ${ }^{20}$ Perang Jambi (1858 - 1907) yang dipelopori oleh Sulthan Thaha Saifuddin, bila ditarik beberapa pengertian di atas, adalah berbentuk perang kekuasaan. Sulthan Thaha Saifuddin pada tahun 1855, yang sebelumnya menjabat sebagai Pangeran Ratu, dengan gelar Pangeran 
Djayadiningrat, menggantikan kedudukan Sulthan Abdur Rahman Nazaruddin sebagai Sulthan di daerah Jambi. Dalam upacara pengangkatannya, dia tidak memberikan pengakuannya terhadap perjanjian antara Sulthan Jambi dengan Belanda, yang dibuat pada tahun 1834, semasa pemerintahan sebelumnya. Karena dia menganggap bahwa perjanjian itu merugikan kesulthanan Jambi. Isi perjanjian itu adalah:

1. Negeri Jambi dikuasai dan dilindungi oleh Negeri Belanda

2. Negeri Belanda mempunyai hak untuk mendirikan kekuatan dalam daerah Jambi dimana perlu. ${ }^{21}$

Pada perjanjian ini, terlihat bahwa Belanda, sudah meletakkan daerah Jambi langsung di bawah pemerintahan Negeri Belanda. Dalam artian bahwa kepentingan Belanda bukan lagi untuk perdagangan, sebagaimana mulanya,tetapi sudah berkisar kepada penjajahan daerah Jambi. Walaupun motivasinya masih berkisar dalam kepentingan perdagangan, yaitu mengawasi perdagangan Belanda di Pantai Timur. Pada tanggal 15 Desember 1834, pemerintah Belanda melalui Residen Palembang Practonis, memperluas perjanjian ini dengan :

1. Pemerintah Belanda memungut cukai dari segala barang yang masuk dan keluar daerah Jambi.

2. Pemerintah Belanda berhak memonopoli penjualan garam.

3. Pemerintah Belanda tidak memungut cukai lainnya.

4. Pemerintah Belanda tidak akan turut campur dalam urusan tata-negara dalam negeri dan tidak akan mengganggu adat istiadat dalam negeri Jambi, kecuali dalam hal penggelapan cukai yang berhak dipungut olehpemerintah Belanda.

5. Kepada Sulthan dan Pangeran Ratu diberikan uang tahunan sebesar 8.000 gulden.22

Pada masa perempatan abad ke 20 ini pemerintah Belanda di daerah Jambi berusaha untuk merubah ekonomi Jambi yang masih sederhana kepada sistim ekonomi yang berorientasi ke pasaran dunia. Dalam rangka usaha ini pemerintah belanda menggalakkan ekspor hasil hutan Jambi berupa damar, getah asli/setengah jadi dan rotan. Perkembangan perdagangan hasil hutan ini tidak mempunyai efek yang berarti terhadap kehidupan rakyat Jambi karena mereka belum ikut serta dalam kegiatan ini. Orang-orang Eropa, Cina dan Bumiputera yang berasal dari luar Jambi memperoleh keuntungan sebagai pedagang perantara. Golongan bumiputera yang berasal dari luar Jambi memang digalakkan oleh Belanda dalam kegiatan ekonomi di Jambi karena penduduk setempat dianggap belum mampu untuk memainkan peranan. Sebagai contoh pada tahun 1911 di Jambi ada 7 perusahaan angkutan sungai, dua di antaranya adalah milik bumiputera yang berasal dari luar Jambi, dua milik cina dan tiga milik orang Eropa. ${ }^{23}$

Dimasa kesultanan, daerah Jambi kota telah menjadi pusat pemerintahan sekaligus ibu kota Kesultanan Jambi. ${ }^{24} \mathrm{Hal}$ initerbukti dari adanya keraton yang terletak di tepian Sungai Batanghari, tepatnya $90 \mathrm{~km}$ dari muara Sungai

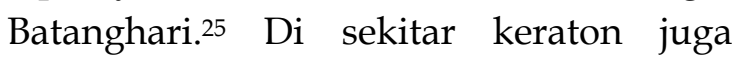
terdapat kediaman bangsawan dan pejabat istana yang jaraknya dari keraton 
disesuaikan dengan tingkatan bangsawan mereka masing-masing. ${ }^{26}$

Didaerah kota inilah, sultan menjalankan pemerintahan atas daerah huluan dan hilir yang menjadi wilayah Kesultanan Jambi. Mengenai wilayah admistratif Kesultanan Jambi Abad ke 1519, dapat dilihat dibawah ini:

1. Wilayah kekuasaan huluan Jambi :

a. Daerah Aliran Sungai Tungkal Ulu

b. Daerah Aliran Sungai Jujuhan

c. Daerah Aliran Sungai Batang Tebo

d. Daerah Aliran Sungai Batang Tabir

e. Daerah Aliran Sungai Batang Merangin

f. Pangkalan Jambi

g. Pedalaman Sumatera Barat ( Sungai Langsat di Sawah Lunto, Siguntur di Pulau Punjung, Rambahan di Dhamasraya

2. Wilayah kekuasaan hilir Jambi

a. Tungkal Ilir

b. Rantau Benar

c. Danau Ambat

d. Batang Tembesi

e. Perbatasan Palembang ${ }^{27}$

Dalam sejarah jatuhnya Jambi ketangan Belanda, rakyat Jambi tidak saja berhadapan dengan kekuatan senjata yang tidak berimbang, tetapi juga dengan adanya tipu daya licik, adu domba dan politik pecah belah yang dilakukan oleh Belanda. Orang-orang yang haus pangkat dan kedudukan serta harta benda selalu diperalat oleh Belanda. ${ }^{28}$ Dilihat dari keadaan pada saat itu Sumatera memiliki banyak sumber daya alam selain jenis tanah yang subur yang cocok untuk perkebunan. Tingkat kepadatan penduduknya yang rendah sehingga memberikan bentangan lahan yang luas dan dapat dibuat perkebunan, yang mana hal tersebut berdampak pada mata pencaharian yang ada di Jambi. ${ }^{29}$ Mata pencaharian dari masyarakat Jambi yaitu bertani. Adapun hasil bumi yang dihasilkan antara lain karet, kopi dan teh. Namun yang paling mendominasi yaitu karet. Sebelum keadaan Jambi yang memanas menjelang keruntuhan Hindia Belanda, keadaan ekonomi masyarakat Jambi makmur yang mana oleh rakyat Jambi disebut Hujan Mas. Kemakmuran ini timbul karena tingginya harga barangbarang hasil bumi seperti karet, kopi dan teh yang dihasilkan oleh masyarakat Jambi. ${ }^{30}$

\section{c. Melayu Jambi Pasca Kemerdekaan dan Awal Pembentukan Provinsi Jambi}

Pemerintah Hindia Belanda di daerah Jambi dalam usahanya melakukan persiapan terhadap kemungkinan serbuan jepang, berusaha mendekati tokoh-tokoh atau pemukapemuka masyarakat di daerah jambi. Pertemuan-pertemuan antara pejabatpejabat pemerintah Hindia Belanda dan pemuka-pemuka ini tidak membawa hasil yang memuaskan sebagaimana tujuan yang diharapkan Belanda dalam menghadapi kemungkinan serangan Jepang ke daerah Jambi. ${ }^{31}$ Peneliti menyimpulkan faktor penting akhir dari pemerintahan Hindia Belanda di Indonesia kususnya di Jambi adalah keadaan politik.

Pasca kemerdekaan di Indonesia ditandai dengan Jepang menyerah Kepada Sekutu. Menyerahnya Jepang kepada Sekutu pada Perang Dunia II tanggal 15 Agustus 1945 menyebabkan Indonesia berada pada situasi kekosongan kekuasaan (vacuum of power). Situasi ini 
menjadi "kesempatan emas" bagi bangsa Indonesia untuk segera memproklamasikan kemerdekaannya. Maka pada tanggal 17 Agustus 1945 Soekarno segera memproklamasikan kemerdekaan Republik Indonesia. Perjuangan bangsa Indonesia setelah ini memasuki tahap baru, yaitu perjuangan membela dan mempertahan kan kemerdekaan terhadap ancaman penjajahan kembali di bumi Nusantara ini. ${ }^{32}$

Pada tanggal 17 Agustus 1945 Republik Indonesia memproklamirkan diri menjadi sebuah negara yang merdeka. Zaman revolusi fisik Indonesia pundimulai, perjuangan-perjuangan dilakukan lewat jalur perundingan maupun tindakan-tindakan revolusioner berupa konfrontasi langsung. Pihak-pihak yang mendukung jalur diplomasi seperti Sutan Sjahrir beranggapan bahwa diplomasi adalah jalan keluar yang paling realistis agar Republik di akui secara de facto oleh dunia internasional khusu snya pengakuan kedaulatan dari Belanda. Sementara pihak lainnya seperti Jenderal Sudirman beranggapan bahwa berunding dengan Pemerintahan Belanda tidak ada gunanya dan hanya akan merugikan Republik saja, tuntutan Merdeka 100\% serta slogan-slogan merdeka atau mati menjadi tujuan perjuangan revolusioner.

Pada saat proklamasi Sumatera menjadi satu provinsi yaitu Provinsi Sumatera dan Medan sebagai ibu kotanya, serta MR Teuku Muhammad Hasan ditunjuk memegangkan jabatan gubernur. ${ }^{33}$ Pada tanggal 18 April 1946, Komite Nasional Indonesia Sumatera bersidang di Bukittinggi dan memutuskan Provinsi Sumatera terdiri dari tiga sub provinsi, yaitu Sub Provinsi Sumatera Utara, Sumatera Tengah dan Sumatera Selatan. Sub Provinsi Sumatera Tengah mencakup Karesidenan Sumatera Barat, Riau dan Jambi. Jambi pada awal Indonesia merdeka adalah sebuah keresidenan yang berada di wilayah Provinsi Sumatera. Jabatan yang memegang wilayah tersebut yaitu Residen Republik Indonesia. Wilayah Keresidenan Jambi yang tadinya satu wilayah menjadi dua wilayah, yaitu wilayah Jambi Hulu (Merangin) yang berkedudukan di Bangko dan wilayah Jambi Hilir berkedudukan di Jambi. ${ }^{34}$

Secara historis Kekuasaan Belanda atas Jambi berlangsung kurang lebih selama 36 tahun karena pada tanggal 9 Maret 1942 terjadi peralihan kekuasaan kepada pemerintah Jepang. Dan pada 14 Agustus 1945 Jepang menyerah pada sekutu. perjalanan perjuangan Revolusi dari Rakyat Jambi serta dilengkapi dengan pembahasan mengenai pembentukan organisasi militer di daerah Jambi yang dipicu oleh kedatangan bala tentara Jepang yang menimbulkan kesengsaraan bagi rakyat Jambi sehingga menimbulkan keinginan rakyat untuk membentuk kekuatan militer pada saat itu. ${ }^{35}$ Semangat nasionalisme berkoar di seluruh penjuru negeri Indonesia, tidak pandang buluh semua rakyat indonesia ikut serta menikmati euforia rasa kemenangan atas Kemerdekaan Bangsa Indonesia atas penjajahan Jepang. Begitu juga dengan daerah Jambi, daerah Jambi menerima berita Proklamasi Kemerdekaan Indonesia pada tanggal 18 Agustus 1945, setelah dr.A.K.Gani dari Palembang melalui telephon menyampaikan berita Proklamasi Kemerdekaan Indonesia 
kepada R. Sudarsono, pimpinan buruh di pertambangan minyak Jambi. ${ }^{36}$

Proklamasi ini disambut gembira oleh masyarakat daerah Jambi yang kemudian membangunkan semangat patriotisme dikalangan pemuda, tokoh masyarakat, alim ulama, cerdik pandai dan semua lapisan masyarakat daerah Jambi untuk terus mempertahankan Kemerdekaan Indonesia. Pasca diterimanya berita Proklamasi Kemerdekaan Indonesia, para tokoh Nasional daerah Jambi segera melakukan pembentukan Badan-badan Perjuangan dan kelengkapan organisasi pemerintahan yang berfungsi sebagai wadah untuk memepertahankan kemerdekaan seperti pembentukan Angkatan Pemuda Indonesia yang diketuai oleh Abunjani dan pembentukan Komite Nasional Indonesia daerah Jambi yang diketuai oleh Makalam. Bendera Merah Putih dikibarkan di puncak menara air oleh para pemuda Jambi, antara lain R. Hoesen, Akipo, dan Amin Aini. Sementara itu, Kantor Pengadilan Jepang (dekat RS. Thersia sekarang) beberapa pejuang, seperti Zuraida, Nuraini, Sri Rexeki, Nurlela, dan Nursiah menurunkan bendera Jepang (Hinomaru) dan menggantinya dengan menaikan bendera Merah Putih. Praktis pada 22 Agustus 1945 bendera Merah Putih berkibar di Jambi dan beberapa kota lainnya di Keresidenan Jambi. Pada tanggal tersebut merupakan awal gerakan kemerdekaan Indonesia di Jambi, yaitu terbentuknya Angkatan Pemuda Indonesia (API) yang diketuai oleh Abunjani. API ini bertugas menjaga ketertiban, keamanan, membela, dan mempertahankan kemerdekaan. ${ }^{37}$
Setelah Indonesia merdeka, Jambi tidak segera menjadi provinsi sendiri, melinkan berada dalam taril-menerik antara masuk wilayah Provinsi Sumatera Tengah atau Selatan. Berdasarkan UU Nomor 10 tahun 1948 yang embagi Simatera menjadi tiga Provinsi, Keresidenan Jambi masuk ke dalam Provinsi Sumatera Tenga bersama Riau dan Sumatera Baratsekarang. Ketika terjadi Agresi Militer Belanda Yang kedua pada Desember 1948, provinsi yang baru lahir itu membekukan diri dan wilyahnya dikuasai militer. Berbeda dengan Sumatera Barat dan Riau. Panglima Tentara dan Territorium Sumatera. Jambi dimasukan ke wilayah Sumatera Selatan serta berada di wilayah Sumatera Selatan serta berada dibawah kekuasaan Gubernur Militer Sumatera Selatan. ${ }^{38}$ Ketika perang usai dan Jambi kembali masuk menjadi bagian Sumatera Tengah, suara-suara ketidakpuasan karena merasa didominasi oleh "orang Minangkabau" kerap terdengar. Puncaknya, pada 25Januari 1957, kongres Pemuda mendesak Badan Kongres Rakyat Jambi (BKRD),badan yang dibentuk dua tahun sebelumnya sebagai wadah perjuangan, untuk mendeklarasikan provinsi baru. 6 Jabuari 1957, deklarasi Provinsi digelar, oleh Dewan Banteng yang menjadi penguasa pemerintah Sumatera Tengah. Keputusan BKRD tersebut disahkan. Gusti Asnan menjelaskan di dalam bukunya Memikir Ulang Regionalisme: Sumatera Barat Tahun 1950-an. Gejolak pembentukan provinsi di Sumatera Tengah ini sebagai tuntutan desentralisasi yang terjadi bahkan jauh sebelum Reformasi. $^{39}$ 
Lebih lanjut lagi, menjadi provinsi kesempatan untuk membangun daerah sendiri lebih terbuka luas. Tetapi, setahun kemudian tepatnya 15 Februari 1958, beberapa wilayah hulu Jambi dan Sumatera Barat terlibat langsung dalam deklarasi Pemerintahan Revolusioner Republik Indonesia (PRRI). Gerakan yang menuntut akan adanya otonomi daerah yang lebih luas itu, yang didukung pula oleh beberapa wilayah di Sulawesi, dianggap suatu pemberontakan oleh pemrintah pusat. Operasi militer kemudian dikerahkan untuk menumpaskannya. ${ }^{40}$ Peristiwa ini berlangsung tidak sebentar melainkan dalam jangka panjang, termasuk Orde Lama jatuh dan digantikan oleh Orde Baru. Rezim yang baru ini sangat meliterstik dan sentralistik ini membuat daerah-daerah yang dimasa lalau pernah menuntut otonomi, namun dibungkam menjadi kian tak berani bersuara. Ada trauma yang mengendap yang mencegah mereka untuk menuntut banyak atau menyatakan keberatan, termasuk ketika di masa itu gubernur Jambi pun di tunjuk dari daerah luar. Pada tahun 1989, barulah Abdurahman Sayuti yang putra daerah dipercaya memegang tertinggi di Provinsi Jambi tersebut hingga 1999 atau awal Reformasi.

\section{Kesimpulan}

Menurut dinamika historis kerajaan Malayu jambi dapat digambarkan sebagai berikut:

1. Kerjaan Malayu 1 yang mulai berkembang kira-kira sebelum tahun 680 M dalam berita dinasti Tang mengatakan bahwa pada tahun 644 dan 645 utusan dagang dari kerajaan
Mo-lu-yo datang ke negeri Cina. Ketika I-tsing mengunjungi Malayu "Jambi" pada tahun $672 \mathrm{M}$ dalam perjalanan ke Nalanda negara masih merdeka, akan tetapi ketika berkunjung lagi tahun $688 \mathrm{M}$, sekembalinya dari nalanda I-tsing mengatakan bahwa Malayu adalah bagian dari Sriwijaya. Kemudian utusan utusan dari Chan-pei muncul kembali di Cina tahun 853 dan 871 . Kutukan di prasasti Karang Brahi di tepi Sungai Merangin di daerah Jambi atas membuktikan bahwa Chan-pei dikuasai oleh Sriwijaya.

2. Kerajaan Malayu II, yang menurut J.G.de Casparis berkembang sekitar abad XI sampai sekitar tahun 1400. Pada waktu itu kerajaan Malayu II telah mengadakan kontak dengan Jawa yaitu adanya Pamalayu tahun 1275 dan pengiriman arca Amoghapasa Lokeswara tahun 1286 ke Padang Roco.

3. Nama kerajaan Malayu III adalah Malayu yang sudah dipengaruhi dengan Islam. Raja sudah bergelar Sultan, Misalnya Sultan Thaha Syaifuddin, Sultan Nazzaruddin, dan lain-lain.

4. Melayu Jambi Pasca Kemerdekaan dan Awal Pembentukan Provinsi Jambi, merupakan berkhirnya kolonialisme di Jambi. Jambi tidak langsung menjadi provinsi, Setelah Indonesia merdeka, Jambi tidak segera menjadi provinsi sendiri, melinkan berada dalam taril-menerik antara masuk wilayah Provinsi Sumatera Tengah atau Selatan. Berdasarkan UU Nomor 10 tahun 1948 yang embagi Simatera menjadi 
tiga Provinsi, Keresidenan Jambi masuk ke dalam Provinsi Sumatera Tenga bersama Riau dan Sumatera Baratsekarang. Ketika terjadi Agresi Militer Belanda Yang kedua pada Desember 1948, provinsi yang baru lahir itu membekukan diri dan wilyahnya dikuasai militer. Berbeda dengan Sumatera Barat dan Riau. Panglima Tentara dan Territorium Sumatera. Jambi dimasukan ke wilayah Sumatera Selatan serta berada di wilayah Sumatera Selatan serta berada dibawah kekuasaan Gubernur Militer Sumatera Selatan. Ketika perang usai dan Jambi kembali masuk menjadi bagian Sumatera Tengah, suara-suara ketidakpuasan karena merasa didominasi oleh "orang Minangkabau" kerap terdengar. Puncaknya, pada 2-5 Januari 1957, kongres Pemuda mendesak Badan Kongres Rakyat Jambi (BKRD),badan yang dibentuk dua tahun sebelumnya sebagai wadah perjuangan, untuk mendeklarasikan provinsi baru. 6 Jabuari 1957, deklarasi Provinsi digelar, oleh Dewan Banteng yang menjadi penguasa pemerintah Sumatera Tengah.

\section{Endnote}

${ }^{1}$ Secara geografis, lalu lintas pelayaran daerah pesisir Jambi berada di pantai timur Sumatera. Keberadaannya ini tidak bisa lepas dari persinggahan pelayaran dan perdagangan Timur Tengah, India, dan Tiongkok. Lihat: Adrianus Chatib, dkk., Kesultanan Jambi dalam Konteks Sejarah Nusantara (Jakarta: Puslitbang Lukturdan Khazanah, 2011), hlm. 7

${ }^{2}$ Giyarto, Selayang Pandang Jambi,(Klaten : Intan Pariwara. 2008), hlm 9
${ }^{3}$ S. Sartono, Kerajaan Malayu Kuno PraSriwijaya di Sumatera di Sumatra, Seminar Sejarah Malayu Kuno, (Jambi: 7-8 Desember 1992), hlm. 2

${ }^{4}$ Ibid., hlm., 3

${ }^{5}$ M.M. Sukarto K. Atmodjo, Kontiunitas Kerajaan Malayu Kuno dan Sriwijaya serta Temuan Prasasti Boom Baru di Palembang, makalah Seminar SejarahMalayu Kuno, (Jambi: 7-8 Desember 1992), hlm. 4

${ }^{6}$ Salamet,Salmet Muljana, Kuntala, Sriwijaya, dan Suwarnabhumi, (Jakarta: Yayasan Idayu, 1981), hlm 26-247

${ }^{7}$ Hasan Djafar, Prasasti Masa Kerajaan Malayu Kuno Dan Beberapa Permasalahan. (Jambi: Kerjasama Pembda Tingkat I Propinsi Jambi Dengan Kantor Wilayah Depdikbud Propinsi Jambi. 1992), hlm 25

\section{${ }^{8}$ Ibid}

${ }^{9}$ George Coedes, "Prasasti Berbahsa Melayu Kerajaan Sriwijaya” dalam Kedatuan Sriwijaya, (Depok: Komunitas Bambu, 2014), hlm. 63-65

${ }^{10}$ Ariwiadi, Ariwiadi, Ikhtisar Sejarah Nasional Indonesia, (Jakarta: Pusat Sejarah Abri, 1978), hlm19

${ }^{11}$ Slamet Muljana, op.cip. hlm. 118

${ }^{12}$ Ibid., hlm. 185

${ }^{13}$ Ibid., hlm. 114

${ }^{14}$ Swarnabumi nama pulau sumatera zaman Adityawarman. Lihat, Usman Meng, Napak Tilas Liku-Liku Provinsi Jambi, (Jambi: Pemerintah Provinsi Jambi, 2006), hlm. 27

${ }^{15}$ Bambang Budi Utomo, Batanghari Riwayatmu Dulu. (Jambi: Kerjasama Pembda Tingkat I Propinsi Jambi Dengan Kantor Wilayah Depdikbud Propinsi Jambi, 1992), hlm, 26-27

${ }^{16}$ Djoened Poesponegoro Marwati,. Sejarah Nasional, 1984, hlm 85, peneliti melihat ada kekurangan dalam pengetahuan tentang raja Adityawarman, menurut Casparis ada dua hal yaang dapat menekan pentingnya peranan Adityawarman. Pertama, raja itu memerintah pada masa kerajaan Majapahit telah mencapai puncak kejayaannya yaitu saat Hayam Huruk berkuasa. Mungkin sekali Adityawarman mengakui kewibawaan kerajaan Majapahit, tetapi hal itu tidak ternyata dari prasastinya, yang tidak pernah menyebutkan ketergantungan Adityawarman dari Majapahit, bahkan nama pulau Jawa pun belum diketemukan dalam prasasti-prasasti raja itu. Kedua, Adityawarman memerintah di bagian pulau Sumatera pada masa bagian utara pulau itu sudah beragama Islam sejak setengah abad, sebagaimana ternyata dari cerita perjalanan Marco Polo pada tahun 1292, hal ini diperjelas lagi dari batu nisan Sultan Malik Al-Saleh di Samudera Pasai, berangka 
tahun 1297. Beberapa tahun lagi ternyta bahwa Agama Islam sudah berakar di Trengganu di pantai Timur Semenanjung Malaka. Memang benar bahwa ada perselisihan mengenai tahun Terengganu tersebut, tetapi Casparis sepenuhnya setuju dengan Profesor Fatimi bahwa batu tulis itu berangka tahun 702 A.H atau tahun 1303 masehi. Dalam Casparis, Kerajaan Malayu dan Adityawarman. 1992, hlm, 2.

${ }^{17}$ Setelah pemerintahan Ananggawarman sebagai raja terakhir yang menduduki tahta kerajaan di Pagaruyung selaku penerus kerajaan Melayu (Adityawarman), maka kerajaan Melayu Pagaruyung pecah menjadi dua bagian. Bagian pertama: Luhak Nan bapanghulu pulang ke Minangkabau. Bagian kedua : Alam nan Barajo kembali ke kerajaan Jambi (Melayu), dan itulah sebabnya putri selaras Pinang Masak kembali ke Jambi (Melayu).

${ }^{18}$ Silsilah raja-raja Jambi dari putri Selaras Pinang Masak; raja Pagaruyung di tanah Jambi, mempunyai empat orang putra yaitu Orang Kayo Pingai, Orang Kayo Kedataran, Orag Kayo Hitam dan orang Kayo Hitam dan satu orang Putri yaitu orang Kayo Gemuk. Kekuasaan kerajaan dipegang secara turun-keturun sampai raja Sulthan Thaha. Lihat, Anonim, Dinas Kebudayaan dan Pariwisata, Silsilah Raja-Raja Jambi, Undang-Undang, Piagam dan Cerita Rakyat Jambi, (Jambi: Alih Aksara Naskah, 2005). hal. 73

${ }^{19}$ Sartono Kartodirdjo, Sejarah Indonesia Baru : 1500 - 1900 Dari Emporium Sampai

Imperium, (Jakarta : PT. Gramedia, 1988), hlm. 109.

${ }^{20} \mathrm{Ibid}, \mathrm{hlm}, 110$

${ }^{21}$ Kementerian Penerangan Republik Indonesia No. 11 Tentang Sumatera Tengah, hlm. 64.

${ }^{22} 8$ Kementerian Penerangan Republik Indonesia, hlm. 65.

${ }^{23} 8$ Jang A. Muttalib, Suatu Tinjauan Mengenai Beberapa Gerakan Sosial di Jambi Pada Perempat Pertama Abad ke 20, (Jakarta: Prisma : 1980), hlm. 32

${ }^{24}$ Kesultana Jambi terbentuk pada abad ke$15 \mathrm{M}$ seiring dengan proses Islamisasi di Sumatera, dengan sultan pertamanya Orang Kayo Hitam dan sultan terakhir Sultan Thaha Syaifudin sampai akhir abad ke $18 \mathrm{M}$, lihat J Tideman, Djambi (Amsterdam: De Bussy, 1938), hlm. 29

${ }^{25}$ Keraton Jambi didirikn oelh Sultan pertama pada abad ke-15, dalam Elsbeth Locher Scholten, hubungan Jambi-Batavia 1830-1907 dan Bangkitnya Imperia;isme Belanda, (Jakarta: Banana, KITLV-Jakarta, 2008), hlm. 40.

${ }^{26}$ Bambang Budi Utomo, Batanghari Riwayatmu Dulu, Makalah, disampaikan dalam seminar Sejarah Melayu Kuno, Jambi, 7 Desember 1992, hlm. 10

${ }^{27}$ G.J. Velds, de onderwiving van Jambi 1901-1907 dalam Indische Militaire Tijdschrift dan A.M. Nasruddin, Jambi Dalam Sejarah Nusantara 692-1949 M, Jambi, tanpa penerbit, 1990, hlm. 6674

${ }^{28}$ Meng Usman, Napak Tilas Propinsi Jambi, (Pemerintah Propinsi Jambi, Jambi: 2006)

${ }^{29}$ Poesponegoro, Marwati Djoened dan Notosusanto Nugroho. 2010. Sejarah Nasional Indonesia V. Zaman Kebangkitan Nasional dan Masa Hindia Belanda. Jakarta : Balai Pustaka. hlm 242

${ }^{30}$ Arifin, Mimin dan Ekawarni. 1986. Sistem Ekonomi Tradisionla Daerah Jambi. Jakarta Departeman Pendidikan dan Kebudayaan. hlm 2124

${ }^{31}$ Depdikbud, 1978, hlm, 89

${ }^{32}$ Tjokropranolo, Panglima Besar TNI

Jenderal Soedirman, Pemimpin Pendobrak Terakhir Penjajahan di Indonesia. (Jakarta: Surya Persindo, 1992), hlm. 43.

${ }^{33}$ D. Rini Yunarti, BPUPKI, PPKI, Proklamasi Kemerdekaan RI, (Jakarta Kompas, 2003), hlm. 145.

${ }^{34}$ Dewan Harian Daerah Angkatan 45 Provinsi Jambi, Sejarah Perjuangan Kemerdekaan R.I (1945-1949) di Provinsi Jambi (Jambi, 1990), hlm 20

${ }^{35}$ Bambang Suwondo, Sejarah Revolusi Kemerdekaan ( 1945-1949) Daerah Jambi, Jakarta: Depdikbud, 1979. Hlm. 59.

${ }^{36}$ Dewan Pimpinan Cabang Legium Vetran RI, Penyusunan Pemerintah Sipil dan Kekuatan Bersenjata Tahun 1945-1949 Di Daerah Jambi, (Jambi : Depdiknas, 2009), hlm. 13.

${ }^{37}$ Dewan Harian Daerah Angkatan 45, Sejarah Perjuangan Kemerdekaan RI (1945-1949) Di Provinsi Jambi, (Jambi : CV.Majelis Raya Offset, 1991). Hlm.15

${ }^{38}$ Gusti Asnan, Memikir Ulang Regionalisme: Sumatera Barat Tahun 1950-an, (Jakarta: Yayasan Obor Indonesia dan KITLV Jakarta, 2007), hlm. 224

${ }^{39}$ Ibid,

${ }^{40}$ R.Z. Leirisa, PRRI Permesta: Strategi Membangun Indonesia Tanpa Komunis, (Jakarta: Grafiti, 2009). 


\section{Referensi}

Adrianus Chatib, dkk., Kesultanan Jambi dalam Konteks Sejarah Nusantara (Jakarta: Puslitbang Lukturdan Khazanah, 2011).

Giyarto, Selayang Pandang Jambi,(Klaten : Intan Pariwara. 2008).

S. Sartono, Kerajaan Malayu Kuno PraSriwijaya di Sumatera di Sumatra, Seminar Sejarah Malayu Kuno, (Jambi: 7-8 Desember 1992).

M.M. Sukarto K. Atmodjo, Kontiunitas Kerajaan Malayu Kuno dan Sriwijaya serta Temuan Prasasti Boom Baru di Palembang, makalah Seminar SejarahMalayu Kuno, (Jambi: 7-8 Desember 1992).

Salamet,Salmet Muljana, Kuntala, Sriwijaya, dan Suwarnabhumi, (Jakarta: Yayasan Idayu, 1981).

Hasan Djafar, Prasasti Masa Kerajaan Malayu Kuno Dan Beberapa Permasalahan. (Jambi: Kerjasama Pembda Tingkat I Propinsi Jambi Dengan Kantor Wilayah Depdikbud Propinsi Jambi. 1992).

George Coedes, "Prasasti Berbahsa Melayu Kerajaan Sriwijaya” dalam Kedatuan Sriwijaya, (Depok: Komunitas Bambu, 2014).

Ariwiadi, Ariwiadi, Ikhtisar Sejarah Nasional Indonesia, (Jakarta: Pusat Sejarah Abri, 1978).

Usman Meng, Napak Tilas Liku-Liku Provinsi Jambi, (Jambi: Pemerintah Provinsi Jambi, 2006) Bambang Budi Utomo, Batanghari Riwayatmu Dulu. (Jambi: Kerjasama Pembda Tingkat I Propinsi Jambi Dengan Kantor Wilayah Depdikbud Propinsi Jambi, 1992).

Djoened Poesponegoro Marwati,. Sejarah Nasional, 1984,

Casparis, Kerajaan Malayu dan Adityawarman. 1992, hlm, 2.

Anonim, Dinas Kebudayaan dan Pariwisata, Silsilah Raja-Raja Jambi, UndangUndang, Piagam dan Cerita Rakyat Jambi, (Jambi : Alih Aksara Naskah, 2005).

Sartono Kartodirdjo, Sejarah Indonesia Baru : 1500 - 1900 Dari Emporium Sampai Imperium, (Jakarta : PT. Gramedia, 1988), hlm. 109.
Kementerian Penerangan Republik

Indonesia No. 11 Tentang Sumatera Tengah

Jang A. Muttalib, Suatu Tinjauan

Mengenai Beberapa Gerakan Sosial di Jambi Pada Perempat Pertama Abad ke 20, (Jakarta: Prisma : 1980)

J Tideman, Djambi (Amsterdam: De Bussy, 1938), hlm. 29

Elsbeth Locher Scholten, hubungan Jambi-Batavia 1830-1907 dan Bangkitnya Imperia;isme Belanda, (Jakarta : Banana, KITLV-Jakarta, 2008).

Bambang Budi Utomo, Batanghari Riwayatmu Dulu, Makalah, disampaikan dalam seminar Sejarah Melayu Kuno, Jambi, 7 Desember 1992.

G.J. Velds, de onderwiving van Jambi 1901-1907 dalam Indische Militaire Tijdschrift dan A.M. Nasruddin, Jambi Dalam Sejarah Nusantara 692-1949 M, Jambi, tanpa penerbit, 1990.

Usman, Napak Tilas Propinsi Jambi, (Pemerintah Propinsi Jambi, Jambi: 2006)

Poesponegoro, Marwati Djoened dan Notosusanto Nugroho. 2010. Sejarah Nasional Indonesia V. Zaman Kebangkitan Nasional dan Masa Hindia Belanda. Jakarta : Balai Pustaka.

Arifin, Mimin dan Ekawarni. 1986. Sistem Ekonomi Tradisionla Daerah Jambi. Jakarta Departeman Pendidikan dan Kebudayaan.

Tjokropranolo, Panglima Besar TNI Jenderal Soedirman, Pemimpin Pendobrak Terakhir Penjajahan di Indonesia. (Jakarta: Surya Persindo, 1992).

D. Rini Yunarti, BPUPKI, PPKI, Proklamasi Kemerdekaan RI, (Jakarta Kompas, 2003).

Dewan Harian Daerah Angkatan 45 Provinsi Jambi, Sejarah Perjuangan Kemerdekaan R.I (1945-1949) di Provinsi Jambi (Jambi, 1990).

Bambang Suwondo, Sejarah Revolusi Kemerdekaan ( 1945-1949) Daerah Jambi, Jakarta: Depdikbud, 1979.

Dewan Pimpinan Cabang Legium Vetran RI, Penyusunan Pemerintah Sipil dan Kekuatan Bersenjata Tahun 1945-1949 Di Daerah Jambi, (Jambi : Depdiknas, 2009). 
Dewan Harian Daerah Angkatan 45, Sejarah Perjuangan Kemerdekaan RI (19451949) Di Provinsi Jambi, (Jambi : CV.Majelis Raya Offset, 1991).

Gusti Asnan, Memikir Ulang Regionalisme: Sumatera Barat Tahun 1950an, (Jakarta: Yayasan Obor Indonesia dan KITLV Jakarta, 2007).

R.Z. Leirisa, PRRI Permesta: Strategi Membangun Indonesia Tanpa Komunis, (Jakarta: Grafiti, 2009). 